\title{
VỀ Hệ THỐNG LẼ HỘI CHUYỂN MÙA CỦA CÁC DÂN TỘC ĐÔNG NAM Á
}

\section{On seasonal change's festivals of the peoples in Southeast Asia}

Ngày nhận bài: 01/9/2016; ngày phản biện: 15/10/2016; ngày duyệt đăng: 21/11/2016

\section{Ngô Văn Doanh*}

\section{TÓM TẮT}

Dù có những khác biệt về thời gian diễn ra lễ hội và về hình thức tổ chức, những ngày lễ hội hay Tết năm mới của nhiều dân tộc Đông Nam Á, về thực chất là những ngày lễ hội thực sự mang ý nghĩa chuyển mùa: cả mùa thời tiết và mùa làm ăn. Tết của Đông Nam Á là mùa "nghỉ ngơ" của không chỉ thiên nhiên mà còn của cả con người. Suốt mấy tháng cuối năm là cả một khoảng thời gian thiên nhiên chuyển mình để bước từ trạng thái cũ (mùa khô) sang một trạng thái mới (mùa mưa). Đây là khoảng thời gian rất đẹp cho con người nghỉ ngơi, vui chơi và làm những công việc không phải đồng áng, vì cái khô đã được làm dịu đi bằng những cơn mưa nhỏ thưa thớt, còn mùa mưa tầm tã thì còn chưa tới. Vào khoảng thời gian này, con người cũng thực sự được nhàn hạ và no đủ vì mùa màng đã thu hoạch xong, lúa đã về đầy kho, trong khi đó thì chưa thể làm đồng áng được vì trời còn lâu mới mưa. Thế là thiên, nhân tương hợp trong mấy tháng chuyển mùa này. Chính hoàn cảnh thiên nhiên đã tạo ra ở Đông Nam Á một nền văn hoá lấy gieo trồng cây lúa làm cơ bản. Và, vòng đời của cây lúa lại trải dài ra gần như hết cả một chu trình thời tiết, từ mùa mưa này đến mùa mưa sau. Rất hay là vòng đời của cây lúa ngắn hơn chu trình thời tiết vài tháng. Kết quả là, mấy tháng chuyển tiếp của khí hậu trở thành quãng thời gian hay những tháng nhàn rỗi nhất trong năm để mọi người tổ chức mọi cuộc vui, mọi lễ thức hội hè. Chính vì thế, Tết năm mới ở Đông Nam Á thường là cả một khoảng thời gian lễ thức, hội hè dài cả một mùa chứ không chỉ diễn ra một vài ngày. Thế rồi, trên cái nền của những lễ hội chuyển mùa chung đó, do những hoàn cảnh lịch sử khác nhau tác động, một số dân tộc ở Đông Nam Á đã khoác lên phức thể lễ hội chuyển mùa truyền thống của mình cái áo choàng của những nền văn hoá hay tôn giáo khác nhau từ bên ngoài du nhập vào. Chính vì thế mới có Tết của Việt Nam, Tết của Lào, Tết của Cămpuchia, Tết của Thái Lan, Tết của Mianma... Dù có khoác thêm tấm áo nào đi nữa, những cái Tết năm mới của Đông Nam Á vẫn toát lên một đặc trưng chung thống nhất: đặc trưng chuyển mùa từ mùa khô sang mùa mưa và từ mùa cấy trồng này sang mùa cấy trồng sau.

Từ khóa: Lê̂ hội chuyển mùa; Đông Nam Á

\section{ABSTRACT}

Though there are some differences on the details, New year ceremonies and festivals of many peoples of Southeast Asia, are really festivals to mark seasonal changes: climate season and business season. New year time of many peoples of Southeast Asia is a "rest season" not only of not only climate, but also business season. Up to now, in Vietnam Central Highlands, after the harvest in the last month (tenth month) of the lunar year, nearly all ethnicities here come to the time of rest lasted two months. These two months are called not eleventh and twelfth, but "the rest months" ("ning nong khei"). The rest months of Vietnam Central Highlands ethnicities fall on March and April. This time is a New year festival time of many peoples in Southeast Asia: Songkran of Thai in Thailand falls on the $12^{\text {th }}, 13^{\text {th }}$ and $14^{\text {th }}$ of April; Khmers in Cambodia usually celebrate their new year days on $13^{\text {th }}$ of April and the festival lasts for three days; Songkal of Laos corresponds to the mid April; Rija Nưgar of Chams in Vietnam falls in the end of April or in the first days of May... Moreover, the word "Songkran" or "Songkal" (Sankranti in Sanskrit or Sankhara in Pali) means the

\footnotetext{
*Phó Giáo sư, Tiến sĩ - Viện Nghiên cứu Đông Nam Á
} 
shift of the sun from one sign of zodiac to another. Sonkran and Songkal is fixed by astrological calculation when the sun moves out of the sign of Pisces into the sign of Aries.

The time of nearly all these seasonal change's festivals falls on the end of dry season, when the harvest is already finished, the rain season is not yet coming. In this quite long seasonal change's time, the peoples have all necessary conditions and enough of everything: food and free time, for celebrating their new year festivals. So, the seasonal change's festival is the most special traditional festival of the peoples in Southeast Asia. During the festival's days, many typical ceremonies and games ofwet rice cultivation's peoples, such as cleaning houses aswell as public places, making offerings to ancestors, releasing of birds and fish, throwing water at one another... are taken place.

So, we can say that seasonal change's festivals play a vital role in many agricultural societies in Southeast Asia, where regular and adequate rainfall isessential to the well-being of the people.

\section{Keywords: seasonal change's festivals; Southeast Asia}

Đành rằng, mọi lễ tết được gọi là "năm mới" của các dân tộc trên thế giới đều mang một ý nghĩa chuyển tiếp linh thiêng từ thời điểm cuối của một chu trình thời gian $c u ̃$ đã qua sang thời điểm đầu của một chu trình thời gian mới sẽ đến; thế nhưng, cái chu trình thời gian cũ và mới lặp đi lặp lại ấy của năm mới lại được biểu hiện ở mỗi vùng văn hoá có khác nhau. Và, do những đặc thù của điều kiện tự nhiên và văn hoá chi phối, tính chất chuyển tiếp linh thiêng của năm mới của các dân tộc Đông Nam Á cũng có sắc thái riêng của mình.

Ngay từ nửa đầu thế kỷ 20 , các nhà khoa học đã nhận thấy tác động to lớn của khí hậu nhiệt đới gió mùa đối với cuộc sống của các cư dân Đông Nam Á ${ }^{1}$. Không phải ngẫu nhiên mà $\mathrm{G}$. Coedes, nhà nghiên cứu Đông Nam Á nổi tiếng người Pháp, đã đưa ra một nhận xét thật xác đáng: "Bán đảo Đông Dương và quần đảo Nam Dương là những xứ nhiệt đới bị gió mùa chi phối. Mặc dù có những biến đổi từ năm này qua năm khác, mà những biến đổi đó có thể gây tác hại đến việc canh tác lúa nước, loại cây trồng cung cấp chất bột chủ yếu, nhưng nhìn chung khí hậu gió mùa ở vùng này tạo nên một thể liên hoàn luân phiên giữa mùa khô và mùa mưa chi phối đời sống của những người dân định cư và chi phối sự luân chuyển của những luồng gió chính quyết định hướng đi cho những người đi biển bằng thuyền buồm." "2 Mà, đại bộ phận người Đông Nam Á lại là những cư dân trồng lúa nước và ăn cơm gạo là chính. Do vậy, từ ngàn đời nay, thời gian năm tháng của người dân Đông Nam Á được tính theo chu trình canh tác cây lúa, nghĩa là, cứ mỗi mùa lúa là tương ứng với một năm. Và bao giờ cũng vậy, bắt đầu mùa mưa là khởi đầu của một năm xuống đồng gieo trồng cây lúa. Còn quãng thời gian cuối mùa khô và đầu mùa mưa, hay thời kỳ chuyển tiếp từ mùa khô sang mùa mưa, là cả một mùa nghỉ ngơi kéo dài cả mấy tháng liền, vì lúa thì đã gặt và đã lên kho, nhưng mùa mưa thực sự thì vẫn chưa đến. Chính vào quãng thời gian nhàn hạ và no đủ này, những người trồng lúa nước ở Đông Nam Á thường tổ chức nhiều lễ hội lớn, mà, một trong những lễ hội lớn đó chính là Tết năm mới.

Chắc chắn việc thời điểm của Tết năm mới trùng với thời gian chuyển mùa và thời lịch của mùa gieo trồng cây lúa nước là có nguồn gốc bản địa Đông Nam Á. Có thể nhận thấy điều này qua hệ thống nông lịch của nhiều dân tộc bản địa miền núi của Đông Nam Á. Ví dụ, hầu như tất cả các tháng trong năm của dân tộc Giẻ - Triêng, một trong những dân tộc thuộc ngữ hệ Môn -

\footnotetext{
${ }^{1}$ Có thể tham khảo: J. Sion, L Asie des moussons, V. 2, Paris, 1929;

${ }^{2}$ G. Coedes, The Indiannized States of Southeast Asia, East-West Center Press, Honolulu, 1968, tr. 3.
} 
Khmer, ở tỉnh Kon Tum (Bắc Tây Nguyên) đều gắn với lịch sản xuất: tháng Giêng (Khay muôi) và tháng Hai (Khay bar) - bắt đầu phát nương; tháng $\mathrm{Ba}$ (Khay pe) - đốt rẫy, thu dọn nương; tháng Tư (Khay poam) - tra lúa sớm; tháng Năm (Khay pdap) - tra lúa muộn; tháng Sáu (Khay hrâu) - làm cỏ lúa sớm và lúa muộn; tháng Tám (Khay tơ hem) - thu hoạch lúa sớm; tháng Chín (Khay tchít) - thu hoạch lúa muộn; tháng Mười (Khay cu diót) - chuẩn bị ăn Tết; tháng Mười Một (Khay cu diót muôi) - làm nhà, cưới xin và ăn Tết; tháng Mười Hai (Khay cu diót bar) - đi tìm nương. Hệ thống lịch pháp của người Bana ở Bắc Tây Nguyên gắn với cây lúa còn cụ thể hơn. Đối với người Bana, thời kỳ sản xuất gồm mười tháng gọi là khay pớ giang bao gồm: tháng Giêng và tháng Hai - làm đất chuẩn bị gieo trồng; tháng $\mathrm{Ba}$ và tháng $\mathrm{Tư} \mathrm{-} \mathrm{trỉa} \mathrm{lúa;} \mathrm{tháng}$ Năm và tháng Sáu - là cỏ lúa; tháng Bảy và tháng Tám - lúa trổ bông; tháng Chín và tháng Mười - thu hoạch; và hai tháng cuối cùng là hai tháng nghỉ (khay ning nơng) - thời gian của lê̂ hội và đón tết. Về cơ bản, lịch của người Xơ Đăng (ở Kon Tum) cũng không khác lịch của người Bana và Giẻ - Triêng là mấy: tháng Một, Hai và $\mathrm{Ba}$ : phát rẫy; tháng Bốn và Năm: trỉa lúa; tháng Sáu và Bảy: làm cỏ; tháng Tám: chuẩn bị cho thu hoạch; tháng Chín và Mười: thu hoạch lúa; tháng Mười Một và Mười Hai: tháng nghỉ ngơi và làm lễ hội. ${ }^{3}$ Không chỉ các dân tộc thuộc ngữ hệ Môn - Khmer, mà cả các dân tộc nói các thứ tiếng Mã Lai - Đa Đảo ở Tây Nguyên cũng đều tổ chức mọi lễ hội lớn của mình, trong đó có Tết năm mới vào hai tháng nghỉ ngơi cuối cùng của năm nông lịch (tháng Giêng của người Tây Nguyên tương ứng với tháng Tư hoặc tháng Năm Dương lịch). Ví dụ, năm của người Giarai gồm: tháng Một (blan sa) và tháng Hai (blan $d o a$ ) là thời gian làm rẫy; tháng $\mathrm{Ba}$ (blan Khâu) và tháng Tư (blan Pă) - thời gian gieo lúa; tháng Năm (blan Roma) và tháng Sáu (blan Năm) thời gian lam cỏ cho lúa; tháng Bảy (blan Juh) và tháng Tám (blan Păn) - gặt lúa sớm; tháng Chín (blan Doa Rơpăn) và tháng Mười (blan Pluh) - thời gian thu hoạch lúa chính vụ; hai tháng cuối cùng của năm không có tên và được gọi là thời gian nghỉ ngơi (blan Ning Nông) ${ }^{4}$. Như vậy là, theo lịch pháp truyền thống của những cư dân bản địa miền núi ở Đông Nam Á, Tết năm mới thực sự mang tính bản địa của nhiều cư dân Đông Nam Á là lễ Tết chuyển mùa giữa mùa khô và mùa mưa. Mà thông thường, mùa mưa ở nhiều khu vực Đông Nam á (như Tây Nguyên, miền Trung và miền Nam của Việt Nam), mùa mưa bắt đầu từ cuối tháng Tư đến tháng Mười Dương lịch và mùa khô bắt đầu từ cuối tháng Mười đến đầu tháng Tư năm sau. Vào cuối mùa khô, sau khi đã thu hoạch mùa màng và làm lễ mừng cơm mới (thường vào tháng Mười Một, Mười Hai hoặc tháng Một Dương lịch), các dân tộc ở Tây Nguyên thường tổ chức hàng loạt những lễ hội lớn nhỏ, trong đó có Tết năm mới. Không khí chuyển mùa của Tết năm mới và tập tục đón Tết của người Êđê được thể hiện thật sinh động trong bài ca lễ Tết của họ: "Đã trọn mùa rét, Đã hết mùa lúa, Theo tục lẹ xua, Chủ làng lễ cúng, Ăn mùng năm mới, Uống tháng ăn năm, Trâu đâm lợn mổ, Bà con làng ho, Ai nấy đều lo, Mùng gùi sắp sẵn..."5. Mà, một trong những lễ hội Tết điển hình của các dân tộc Tây Nguyên và vùng núi của các tỉnh duyên hải miền Trung Việt Nam là Tết Htend của người Hre.

Như nhiều dân tộc khác trên Tây Nguyên, người Hre đón Tết vào đầu năm Nông lịch, khi mùa khô đã qua, trời đã bắt đầu có mưa và cây cối bắt đầu nẩy lộc (vào khoảng tháng Tư dương lịch). Sau những ngày chuẩn bị Tết (giã gạo, ủ rượu cần, lau chùi cồng chiêng, sửa soạn vòng cườm và áo váy, gói bánh, trang trí nhà cửa, cổng làng...), mọi người hồi hộp chờ đón ngày đầu tiên của năm. Khi mặt trời thức dậy, lễ thức đầu tiên mọi nhà đều làm là lễ Hvang Hnim (tống tiễn tà ma và những cái xấu đi để đón cái tốt và niềm vui

\footnotetext{
${ }^{3}$ Xem thêm: Các dân tộc tỉnh Gia Lai- Công Tum, Nxb Khoa học xã hội, Hà Nội, 1991.

${ }^{4}$ Cụ thể, có thể tham khảo: Ngô Văn Doanh, Lễ hội Rija Nuggar của người Chăm, Nxb Văn hoá dân tộc, Hà Nội, 1999.

${ }^{5}$ Dân ca Tây Nguyên, Nxb Văn hoá, Hà Nội, 1986, tr.69.
} 
đến). Tiếp đến là lễ cúng mời các thần linh và tổ tiên về ăn Tết và phù hộ cho mọi người. Sau hai lễ thức trên, mọi người gói bánh nếp, thịt lợn, gà... để chuẩn bị cho lễ cúng trâu ngày hôm sau ( $T a$ Hreo $\mathrm{Capo}^{\prime}$ ). Lễ cúng trâu được tổ chức ngay trước cửa chuồng trâu vào tảng sáng ngày thứ hai của Tết với mục đích cầu mong cho con trâu (con vật thân thiết giúp con người kéo gỗ, cày bừa...) được mạnh khoẻ và biết nghe lời người. Sau đấy chủ nhà dọn cơm, thịt, rượu... mời mọi người cùng ăn uống. Bên các ché rượu cần, mọi người tâm tình, trò chuyện, đánh cồng, nhảy múa, chơi các trò chơi truyền thống... suốt cả ngày và cả đêm. Sang ngày thứ ba, ngày cuối cùng, các gia đình dọn dẹp nhà cửa sạch sẽ, bày ché rượu ngon ra giữa nhà để đón bà con làng xóm tới thăm hỏi, chúc tụng. Đến thăm nhau, chủ và khách chúc nhau: "cái ốm bỏ đi, làm gì được nấy", "người khoẻ, thóc đầy"... Trước kia, những cuộc thăm viếng và vui chơi đầu năm có thể kéo dài tới mươi ngày, nửa tháng mới hết Tết Htend.

Không chỉ các dân tộc bản xứ chưa chịu sự tác động của các nền văn hoá lớn của Đông và Nam Á (tức của Trung Quốc và Ấn Độ), mà hầu hết các dân tộc lớn cư trú tại các vùng đồng bằng lớn ven biển và đã tiếp nhận những ảnh hưởng của văn hoá Ấn Độ trong khu vực cũng đều đón Tết năm mới vào khoảng thời gian chuyển tiếp giữa mùa khô và mùa mưa (trong tháng Tư Dương lịch). Tại Lào, hội lớn nhất trong thời gian chuyển mùa là lễ Tết Pimay (tên gọi tắt của nhóm từ cút xổng can pimay, nghĩa là ngày cuối cùng của năm cũ sắp hết, ngày đầu năm mới sắp đến), cũng còn gọi là hội năm mới, hay hội té nước. Như người Lào, các dân tộc khác ở Đông Nam Á lục địa như người Thái ở Thái Lan, người Khơme ở Cămpuchia và người Miến ở Mianma cũng đón Tết năm mới của mình vào tháng Tư Dương lịch, thời kỳ chuyển mùa từ mùa khô sang mùa mưa. Và một trong những nét đặc trưng chung nhất cho Tết năm mới (Bun Py mày của người Lào, Song- kran của người Thái, Chon Chnam Thamay của người Khơme và Thagyarmin của người Miến) là tục té nước để tẩy rửa những cái cũ đi và để cầu nước cho cả một năm mới.

Thế nhưng, do chịu ảnh hưởng của các tôn giáo của Ấn Độ như Bàlamôn giáo và Phật giáo, các dân tộc Thái, Lào, Miến và Khơ Me đã phủ lên lễ hội nông nghiệp truyền thống của mình những sắc màu tôn giáo. Nơi chủ yếu diễn ra những lễ thức của Tết năm mới là các ngôi chùa Phật giáo và những người làm những lễ thức chính đầu năm cũng là các nhà sư. Và, các dân tộc Thái, Lào và Khơ Me đã linh thiêng hoá nguồn gốc ngày Tết năm mới của mình bằng câu chuyện huyền thoại về đầu của một vị thần. Người Thái ở Thái Lan kể rằng, xưa kia, trên mặt đất có một ông vua thần kỳ lấy một bà hoàng hậu xinh đẹp. Họ sinh ra được mười hai cô con gái. Khi cô con gái đầu sinh ra, nhà vua vẽ hình con chuột và đặt tên cô là Tủng Nữ, nghĩa là "người bảo hộ chuột”. Con chuột trong tranh lập tức biến thành chuột thật để cô gái chơi. Khi cô gái thứ hai ra đời, nhà vua vẽ hình một con bò và đặt tên con gái là Tủng Vuatupua, nghĩa là "người bảo hộ bò". Con bò trong tranh cũng hoá thành bò thật. Cứ như vậy, nhà vua biến mỗi người con gái thành một người bảo hộ cho một con vật vốn mang tên cho từng năm sinh của từng cô gái. Sau một thời gian trị vì trên mặt đất, nhà vua quyết định về trời. Thế nhưng, khi ông đang bay, một trận cuồng phong nổi lên, và sấm sét chém đứt đầu nhà vua. Cái đầu rơi xuống đất. Mọi người không nhận ra đó là chiếc đầu của ai. Khi tới nơi xem, mười hai cô công chúa nhận ra đó là đầu của cha mình. Trên đường về, các cô công chúa thoả thuận: mỗi người cất giữ đầu cha một năm. Cái đầu được gọi là Song Kran. Từ đó, mỗi khi người con gái này chuyển chiếc đầu của cha mình cho người con gái kia, thì mặt đất cũng bước sang một năm mới. Và vì thế, Tết năm mới của người Thái được gọi là Song Kran. Tết năm mới Song Kran của Thái Lan diễn ra vào những ngày giữa tháng Tư Dương lịch và thường kéo dài 3 - 4 ngày. Riêng ở bắc Thái Lan, Tết năm mới kéo dài tới 5 - 6 ngày và được gọi là Tết Pimay (té nước). Vào ngày đầu tiên, mọi người bắn súng đuổi tà 
ma, tắm rửa giặt rũ, gội đầu, làm vệ sinh nhà cửa... để tẩy sạch những nhơ bẩn của năm cũ. Ngoài ra, ngày hôm đó cũng là ngày dâng đồ ăn lên chùa và biếu quà cho những người cao tuổi. Sang ngày thứ hai, nhà nhà đem cát lên chùa để làm tháp cát để cầu may và thi nhau phóng sinh chim thú để làm phúc và tích đức. Ngày thứ ba là ngày tắm các tượng Phật và đồng thời là ngày hội té nước tưng bừng. Những ngày sau đó là những ngày vui chơi, hội hè, đến nhà nhau thăm hỏi.

Người Lào cũng có câu chuyện về sự tích Tết năm mới tương tự của người Thái. Câu chuyện của người Lào kể rằng, ngày xưa, có một chàng trai, con một gia đình giàu có, tên là Thăm Maban Cumman. Chàng là người thông minh, học rộng và còn biết cả tiếng các loài vật. Tiếng tăm của chàng trai bay đến tai thần Kabin Laphôm trên trời. Thần quyết định thử tài Thăm Maban. Một hôm, thần xuống trần gặp chàng trai và nói: "Nghe nói người là người tài giỏi. Vậy ta hỏi ngươi ba câu. Nếu ngươi trả lời đúng, ta sẽ tự chém đầu dâng nhà ngươi; ngược lại, nếu ngươi không trả lời được, thì nhà ngươi cũng sẽ bị mất đầu với ta. Ba câu hỏi đó là: 1) Buổi sáng chỗ thiêng của con người ở đâu? 2) Buổi trưa chỗ thiêng của con người ở đâu? và 3 ) Buổi tối chỗ thiêng đó ở chỗ nào trong con người?’' Cảm thấy không trả lời ngay được, Thăm Maban Cumman hẹn sau 7 ngày sẽ trả lời thần. Thế rồi, sắp đến ngày hẹn, mà Thăm Maban vẫn chưa tìm ra lời giải cho ba câu hỏi. Buồn bã, chàng trai lang thang vào rừng cây thốt nốt và ngả lưng ngủ đêm ở đấy. Đột nhiên, chàng trai nghe thấy đôi vợ chồng chim đại bàng trong tổ trên ngọn cây nói chuyện với nhau. Chim vợ hỏi chim chồng ngày mai sẽ ăn gì; chim chồng trả lời là sẽ ăn thịt người vì Thăm Maban sẽ chết do không trả lời được câu hỏi: "chỗ thiêng của con người ở đâu vào buổi sáng, buổi trưa và buổi tối?" của thần Kabin Laphôm. Tò mò, chim vợ hỏi chim chồng: "thế phải trả lời thế nào?" Chim chồng nói: "câu hỏi thật dễ. Buổi sáng, chỗ thiêng của con người ở mặt, do vậy mà người ta mới rửa mặt vài buổi sáng. Buổi trưa, chỗ thiêng ở ngực, nên người ta rửa ngực. Còn buổi tối, chỗ thiêng ở chân, nên trước khi đi ngủ, người ta rửa chân.” Ngày hôm sau, đúng hẹn, Thăm Maban lấy ý của chim đại bàng trả lời câu hỏi của thần Kabin Laphôm. Thần chịu thua và phải chịu chặt đầu. Trước khi chặt đầu, thần Kabin Laphôm gọi cả bảy người con gái của mình đến và dặn; "Bố sẽ phải chặt đầu dâng cho Thăm Maban. Thế nhưng, nếu đầu bố mà rơi xuống đất sẽ sinh ra lửa thiêu cháy tất cả; nếu đầu bố ở trên trời thì sẽ sinh ra hạn hán; còn nếu đầu bố rơi xuống biển thì biển sẽ khô cạn. Do đó, các con hãy đem đầu bố đựng vào cái mâm rồi đưa đi cất giữ trong hang Khăn Thu Maly trên núi Khâu Caylạt. Thế là từ đó, bảy người con gái của thần Kabin Laphôm thay nhau, mỗi năm một người đi lấy đầu bố về tắm rửa và rước vòng quanh nhân gian một vòng rồi lại đưa về cất trong hang. Cũng từ đó mới có tục té nước hàng năm vào dịp Tết.

Như của người Thái, Tết năm mới của người Lào rơi vào tháng cuối cùng của mùa khô. Vào tháng này (tháng Năm Phật lịch, tháng Tư Dương lịch), thời tiết nóng bức, nhưng đã có một vài trận mưa nhỏ báo hiệu đầu mùa mưa. Sau Tết năm mới, những trận mưa bắt đầu trút xuống và cây cối, sau một mùa khô trụi lá, bắt đầu đâm chồi nảy lộc. Như vậy, Tết năm mới của người Lào là những ngày lễ hội chuyển mùa, cầu mưa, tống tiễn những rủi ro của năm cũ để đón chào những điều tốt lành cho năm mới. Đối với người Lào, Tết năm mới là hội năm mới (bun py mày) và thường kéo dài 3 - 4 ngày liền. Vì chịu ảnh hưởng của Phật giáo, nên trong những ngày Tết, mọi người đều đến chùa dâng thức ăn cho sư, làm lễ tắm Phật, nghe đọc kinh, đem cát đến chùa làm các núi cát... Thế nhưng, bên cạnh các nghi lễ Phật giáo, trong các ngày Tết của người Lào, còn diễn ra nhiều nghi thức truyền thống đặc sắc, như rước nàng chúa xuân và đặc biệt là hội té nước. Trong đám rước Nàng Chúa Xuân, cô gái được chọn là Chúa Xuân (Nàng Xăng Khản) ngồi trên lưng con vật của năm, còn sáu cô người đẹp kia (bảy cô gái đóng vai bảy người con gái của thần Kabin Laphôm) thì ngồi xung quanh Chúa Xuân. Sau khi đã rước Chúa Xuân đi 
quanh khu vực, mọi người về chùa nghe kể sự tích ngày Tết và chúc nhau bằng té nước. Thế là bắt đầu hội té nước tưng bừng, náo nhiệt. Không phải ngẫu nhiên mà người Lào còn gọi Tết năm mới của mình là Hội té nước (Bun hốt $n a ̣ ̆ m)$. Và, sau Tết té nước, mọi người lại bắt đầu bước vào một năm làm ăn mới.

\section{Chon Chnam Thamay hay Pithi Chon}

\section{Chnam Thamay hay Bân Chon Chnam}

Thamay có nghĩa là Lễ vào năm mới của người Khơ Me ở Cămpuchia và ở miền Nam Việt Nam. Chon Chnam Thamay là Tết hàng Năm của người Khơ Me, nếu tính theo Phật lịch, thì thường diễn ra vào các ngày 13,14 và 15 tháng Chett (khoảng giữa tháng Tư Dương lịch), còn theo năm thời tiết, thì vào những ngày cuối mùa khô và đầu mùa mưa. Vào thời điểm này, trời nắng gắt, nóng bức, nhưng thỉnh thoảng vẫn có một vài cơn mưa rào ngắn ngủi báo hiệu cho mùa mưa sắp tới. Vì thế, sau một mùa chết lá, gặp mưa, cây bắt đầu đâm chồi nẩy lộc. Đối với người Khơ Me, Chon Chnam Thamay không chỉ là lễ vào năm mới mà, sâu xa hơn, chính là lễ mừng chấm dứt thời kỳ (mùa) nắng hạn để bước sang thời kỳ (mùa) mưa nhiều để chuẩn bị vụ mùa mới. Ngoài ra, như ở nhiều dân tộc Đông Nam Á khác, lễ vào năm mới của người Khơ Me còn là thời kỳ nghỉ ngơi, vui chơi giải trí khi mùa màng đã thu hoạch xong.

Người Khơ Me tin rằng, mỗi năm có một vị thần tiên trên trời được trời sai xuống để chăm lo cho cuộc sống của trần gian năm đó, hết năm lại trở về trời để vị thần tiên khác xuống hạ giới. Do vậy, vào đêm giao thừa, nhà nào cũng làm cỗ cúng tiễn vị thần cũ, đón vị thần mới và cầu mong vị thần tiên mới ban phước lành. Như người Lào và người Thái, người Khơ Me cũng có "sự tích Tết năm mới" của mình. Sự tích năm mới kể rằng, ngày xưa, có một vị quốc vương sinh hạ được một hoàng tử thông minh tên là Thommaban. Tiếng đồn về trí tuệ của hoàng tử khiến cho vị thần bốn mặt Kabinh Mahaprum chuyên xuống trần thuyết pháp phải ghen tức và tìm cách hại hoàng tử. Mọi việc sau đó diễn ra như trong câu chuyện sự tích năm mới của người Lào: vị thần đưa ra ba câu đố khó cùng điều kiện thắng thua rất khốc liệt (người thua mất đầu); thế rồi, nhờ biết tiếng của chim, hoàng tử tìm ra lời giải cho câu đố và thắng cuộc. Phần kết sự tích năm mới của người Khơ Me thì lại giống như câu chuyện của người Thái: "Thua cuộc, vị thần ngửa mặt lên trời gọi bảy cô con gái (giống với sự tích của Lào, chứ không phải mười hai cô trong sự tích của người Thái) đến và truyền rằng: "Sau khi cha chết, các con hãy đem đầu cha cho vào trong một ngôi tháp, đừng để người trần gian chạm tới, vì nếu họ bỏ đầu cha xuống biển thì biển cạn khô, quăng lên trời thì không có mưa, để trên mặt đất thì đất khô hạn”. Dặn dò xong, thần rút gươm vàng cắt đầu trao cho cô con gái lớn tên là Tungsa. Vị nữ thần để đầu cha vào cái âu vàng, rồi cùng sáu cô em đưa đầu cha đặt vào ngôi tháp xây trong hang thuỷ tinh trên đỉnh núi Kalata của dãy Himalaya. Từ đó về sau, mỗi năm một lần, đúng ngày thần Kabinh Mahaprum tự sát, bảy cô con gái lại xuống trần vào tháp bưng cái đầu bốn mặt của cha mình đến núi Tudi, đi vòng quanh chân núi ba lần. Tuy cùng xuống trần, những mỗi lần chỉ một cô gái được bưng đầu cha mình. Chính tính tình của cô gái được bưng đầu cha mình sẽ có tác động xấu hoặc tốt cho dân chúng trong năm đó. Sau giao thừa, là đến ba ngày Tết trang trọng, vui vẻ và tưng bừng diễn ra tại chùa.

Những ngày Tết của người Khơ $\mathrm{Me}$ thực sự là những ngày hội vừa thành kính vừa vui nhộn tưng bừng. Ngày thứ nhất là ngày làm lễ rước Đại lịch Maha sangkram (thay cho việc rước đầu vị thần bốn mặt Kabinh Mahaprum, mà theo truyền thuyết, ngày thần tự sát trở thành ngày đầu năm mới). Ngày thứ hai là ngày làm lễ dâng cơm và đắp núi cát để cầu mưa, cầu phúc. Các lễ trên diễn ra tại các ngôi chùa Phật. Trong những ngày Tết, khi những người lớn ngồi nghe thuyết pháp trong chùa, thì trong khuôn viên chùa, nam nữ thanh niên tổ chức nhiều trò chơi tập thể như đá cầu, bịt mắt bắt dê, ném chung (như ném còn của người Thái ở Việt Nam), hát đối đáp, kéo co... 
Và, sang ngày thứ ba mới thực sự là ngày hội nước. Vào ngày cuối cùng này của tết, mọi người làm lễ tắm tượng Phật, tắm cho sư và tắm cho mình.

Truyền thuyết của người Mianma kể rằng, thuở xưa, xưa lắm, khi ấy cả mặt đất không hề có sự sống và đắm chìm trong bóng tối. Thấy tình cảnh như vậy, Thagyarmin, chúa tể của các thần (tiếng Miến gọi là $N a t$ ) bèn ra lệnh cho Mặt Trời và Mặt Trăng chiếu sáng mặt đất. Nhờ có ánh sáng mà dần dà con người, loài vật và cỏ cây hình thành. Khi mặt đất đã có cuộc sống, thần Thagyarmin về trời. Lúc chia tay, vị thần sáng tạo tối thượng hứa với mọi người là hàng năm sẽ trở lại mặt đất vào dịp năm mới. Bởi vậy, người Mianma lấy tên thần Thagyarmin để gọi ngày Tết năm mới của mình. Và, Tết năm mới của người Mianma, cũng như Tết của các dân tộc khác ở Đông Nam Á, là lễ hội chuyển mùa.

Năm nào cũng vậy, khi mùa khô gần hết (khoảng đầu tháng Tư Dương lịch), người Mianma, đặc biệt là các thầy chiêm tinh đều giở tờ giấy bói Thingyansar ra xem để đoán những điềm gì sẽ tới trong năm mới sắp đến và thần Thagyarmin sẽ giáng trần cùng con vật cưỡi gì và sẽ cầm những vật gì trong tay. Theo truyền thuyết, vì không chỉ là Nat tối cao mà còn là vị thần coi giữ các giáo thuyết của đức Phật, nên vật mà năm nào thần Thagyarmin cũng đem theo là hai quyển sổ thiên tào, một bằng vàng và một bằng da chó. Tên tuổi của những người lương thiện được ghi vào sổ vàng và ngược lại của những người xấu - vào sổ da chó. Chính yếu tố Phật giáo đã biến năm mới của người Mianma thành mùa của những ngày hội thụ giáo (các gia đình gửi con vào chùa). Do vậy, suốt những ngày Tết năm mới, ở Mianma đâu đâu cũng thấy những túp lều vải sặc sỡ đủ màu mới mọc lên hai bên đường để làm lễ thụ giáo và nhận đồ dâng cúng cho các chùa. Thế nhưng, nghi lễ khởi đầu cho những ngày năm mới là té nước. Và thật lý thú và đầy ý nghĩa, chính con trẻ là những người đầu tiên được phép té nước vào người thân trong nhà và khách qua đường. Sau sự mở đầu của trẻ em, người lớn mới bước vào cuộc vui té nước. Mọi người vui đùa té nước vào nhau. Ai nấy đều vui sướng vì nước sẽ rửa sạch đau buồn, lo lắng của năm cũ, vì nước sẽ đem lại hạnh phúc, sẽ đem lại những tận mưa tốt lành và mùa màng tươi tốt. Sau những trận té nước tưng bừng, mới tới thời điểm trang trọng của ngày lễ Tết. Mọi người mặc quần áo đẹp nhất, lên chùa làm lễ tắm tượng Phật và cầu kinh. Cho đến nay ở Mianma, mọi người còn giữ lại một phong tục linh thiêng: lễ phóng sinh. Trước khi bước sang năm mới, mọi người trả lại tự do cho những con vật: chim được thả khỏi lồng; gà, vịt được thả khỏi chuồng, trâu bò già được tháo ách...

Người Bali trên đảo Bali (Inđônêxia) là những người theo đạo Bàlamôn chứ không phải là những tín đồ Phật giáo như người Mianma, người Thái, người Lào và người Khơ Me; thế nhưng, Tết năm mới của họ (nepi) cũng là lễ hội chuyển mùa và luôn diễn ra vào đầu mùa xuân (cũng vào khoảng tháng Tư Dương lịch, tháng cuối cùng của mùa khô). Năm Âm lịch của người Bali kết thúc bằng nghi thức làm sạch làng mạc, vườn tược, nhà cửa vào ngày trăng lặn của tháng cuối mùa khô. Trước năm mới hai ngày, người Bali bao giờ cũng làm lễ Melis. Khi vào 1ễ, những đoàn rước sặc sỡ, đem theo các đồ tế, từ các làng kéo ra bãi biển hoặc bờ sông. Các tượng thần trong nhà, trong các đền thờ, được mang đặt lên kiệu khiêng cùng đám rước. Những người tham dự lễ cầm cờ phướn, giáo mác, chậm rãi bước đi theo nhịp nhạc của dàn nhạc gamelang. Khi đã tập hợp đông đủ ở bờ biển (hoặc bãi sông), người ta bắt đầu làm lễ. Các bức tượng được đặt lên một bục cao; cờ phướn, lọng ô cắm trước bục; đồ tế được xếp thành từng đống hình tháp. Sau lễ Melis là ngày tất niên, ngày nghỉ ngơi để chuẩn bị cho những ngày Tết.

Đối với người Bali, ngày đầu năm mới là ngày tế máu cho các thần. Khắp nơi, trước cổng các ngôi đền, trên các sân bãi của làng..., đâu đâu cũng diễn ra các cuộc chọi gà. Những con gà bị chết trong các cuộc chọi gà mang tính nghi lễ này được đem hiến tế cho các thần. Người ta đem 
những con vật đẫm máu này đến chân các đèn tháp cao dâng tế cho thần Mặt trời, thần Biển, thần Núi, thần Đất... để cầu mong mưa thuận gió hoà, mùa màng tươi tốt. Ngoài những con gà tế, người ta còn phải có những đồ dâng tế riêng dành cho các vị thần tối cao và hai vị hung thần Buta và Kala. Đồ tế cho các vị thần tối cao thường là một con ngỗng trắng và một con ngống đen. Còn đồ tế cho Buta và Kala lại là một con trâu đen (xếp ở chính giữa) và tám con vật khác (xếp quanh con trâu đen theo tám hướng, bắt đầu từ hướng đông): bê non, vịt, hươu, chó, mang, công, lợn, dê. Khi các đồ tế được đặt đúng chỗ, ông thầy cúng làm lễ mời các hung thần về nhận đồ lễ. Đãi tiệc các hung thần xong, dân làng mới bắt tay vào tẩy rửa nhà cửa bằng lễ thức vẩy nước thiêng tưng bừng và náo nhiệt. Mọi người hò reo; đánh trống, đánh mõ; đốt đèn, đốt đuốc; chạy tới, chạy lui; vẩy nước đuổi tà ma khỏi nhà, khỏi vườn tược, khỏi làng xóm... Hai hung thần Buta và Kala, vừa được một bữa no, cũng phải hoảng sợ, bỏ chạy khỏi làng. Sở dĩ người Bali làm như vậy là vì họ tin rằng, năm mới đến là Diêm vương (thần Yama) sẽ quét sạch ra khỏi các tầng địa ngục những hồn ma, bóng quỷ của đảo Bali để hòn đảo nảy trở nên trong sạch. Vì vậy, năm mới đối với người Bali là lễ tống ôn xua đuổi tà ma, quỷ dữ ra khỏi làng.

Sau những ngày hiến tế, tắm tượng thần và tống ôn, là đến ngày cuối của Tết. Khác hẳn những ngày trước náo nhiệt và tưng bừng, ngày cuối cùng hoàn toàn tĩnh lặng và bất động: không nấu nướng, không làm việc và cả không sinh hoạt vợ chồng và không ai ra khỏi nhà. Vào ngày này, duy nhất chỉ có một hoạt động là những cuộc thi kéo co được tổ chức tại quẩng trường chung của làng. Tham gia trò chơi có cả trai và gái, trai một bên và gái một bên. Chúng cùng hò reo kéo sợi dây mây to cho đến khi một bên thắng mới thôi.

Sau ngày bất động, người dân đảo Bali lại bước vào một năm làm ăn mới đầy lo toan, vất vả và cũng không kém niềm vui và hy vọng 6 .

Vì nhiều lý do khác nhau tác động tới, trong đó chủ yếu là những lý do về thời tiết, cho nên Tết năm mới của nhiều dân tộc ít người ở miền Bắc Việt Nam và của người Việt ở Việt Nam thường đến sớm hơn một vài tháng so với mùa Tết của các dân tộc khác của Đông Nam Á. Do chế độ gió mùa tạo nên một vùng tiểu khí hậu có phần khác biệt, nên ở miền Bắc Việt Nam, giai đoạn chuyển mùa rơi vào tháng Chạp, tháng Giêng Âm lịch (tháng Hai và tháng $\mathrm{Ba}$ Dương lịch). Theo các nhà nghiên cứu, phần bắc của lãnh thổ Việt Nam, tính từ Hoành Sơn (đèo Ngang) ở khoảng vĩ tuyến 18 độ Bắc trở ra, thuộc miền khí hậu phía Bắc với nét đặc trưng là: khí hậu nhiệt đới gió mùa có mùa đông lạnh (khoảng 3 tháng). Có hai yếu tố ảnh hưởng đến đặc tính mùa đông của miền Bắc Việt Nam: những đợi nắng ấm (chiếm tới $50 \%$ số ngày trong mùa) và sự thâm nhập của gió mùa cực đới. Tuy là mùa khô, nhưng vào cuối mùa đông, sự xâm nhập của gió mùa cực đới thỉnh thoảng vẫn đem lại những ngày có mưa nhỏ. Chính những trận mưa nhỏ thường được gọi là "mưa phùn" hay "mưa bụi" nổi tiếng này làm cho mùa khô ở miền Bắc bị rút ngắn. Dù mùa hè mới là mùa mưa và kéo dài, cũng như các miền khác, từ tháng Tư đến tháng Mười Dương lịch, nhưng ở miền Bắc, thời gian từ cuối tháng Một đến giữa tháng $\mathrm{Ba}$ lại là thời kỳ ẩm ướt nhất trong năm ${ }^{7}$. Và mấy tháng ẩm ướt này thường là khoảng thời gian của mùa xuân (ví dụ, ngày lập xuân của năm 2005 là ngày 4 tháng Một, tức 24 tháng Mười Một Âm lịch). Do vậy, thời gian chuyển mùa từ mùa khô sang mùa mưa ở Bắc Việt Nam (và cả vùng núi phía bắc Đông Nam Á lục địa nữa) không phải là những tháng khô nóng như thường lệ đối với vùng khí hậu nhiệt đới gió mùa Đông Nam Á, mà là cả một thời kỳ ẩm ướt. Dù có một số khác biệt nhưng cũng như ở các nơi khác trong khu vực, thời

\footnotetext{
${ }^{6}$ Chúng tôi đã giới thiệu các lễ tết năm mới của một số dân tộc Đông nam Á trong các công trình: Phong tục các dân tộc Đông Nam Á, Nxb. Văn hoá dân tộc, Hà Nội, 1997; Lễ họi Rija nurgar của người Chăm, Sdd.

${ }^{7}$ Xem: Lê Bá Thảo, Việt Nam- lãnh thổ và các vùng địa lý, Nxb Thế giới, Hà Nội, 1998, tr. 71-73.
} 
kỳ chuyển mùa của người Việt và nhiều dân tộc ít người ở miền núi phía Bắc Việt Nam và Đông Dương là lúc vụ mùa đã thu hoạch hoàn tất; và thời gian xuống đồng vào vụ làm ăn chính (gieo cấy lúa cũng bắt đầu vào tháng Tư Dương lịch, tức đầu mùa mưa. Thế nhưng, vì có cả một mùa xuân ẩm ướt trước khi sang mùa mưa, cho nên khác với ở các vùng khí hậu nhiệt đới khác trong khu vực Đông Nam Á, các dân tộc ở miền Bắc Việt Nam bắt đầu một năm sản xuất sớm hơn. Không ít những câu ca dao và tục ngữ của người Việt đã khắc hoạ khá rõ tiết trời và lịch làm ăn của người nông dân Việt ở Bắc Bộ. Ví dụ như những câu sau của một bài ca dao: "Tháng Chạp là tháng trồng khoai; tháng Giêng trồng đậu, tháng hai trồng cà; Tháng Ba cày võ ruộng ra; Tháng Tu làm mạ, mua sa đầy đồng; Ai ơ cùng vơ cùng chồng; Chồng cày vơ cấy trong lòng vui thay!..." Và Tết của người Việt chính là khởi đầu cho những ngày nghỉ ngơi, vui chơi đầu năm sau cả một năm làm ăn vất vả. Điều này cũng được nói rõ trong câu ca dao: "Tháng Giêng ăn Tết ở nhà; tháng Hai cò̀ bạc, tháng Ba hội hè."; để rồi, sau đó từ tháng Ba trở đi sẽ phải xuống đồng cày cấy. Tính chuyển mùa của năm thời tiết cũng như của năm làm ăn trong cái Tết của người Việt thật là rõ. Và, những biểu hiện về một khoảng thời gian nghỉ ngơi, về những ngày hội hè liên tục tại khắp các làng quê và về những mục đích cầu mưa gió thuận hoà, phồn thực âm dương... của nhiều lễ hội xuân đã phần nào cho thấy, như nhiều dân tộc ở Đông Nam Á (như các dân tộc ở Tây Nguyên...), người nông dân Việt Nam xưa kia vốn có cả những tháng nghỉ ngơi, vui chơi, hội hè vào cuối năm cũ và đầu năm mới, hay vào khoảng thời gian chuyển mùa, mà cụ thể là mùa xuân. Rất có thể, do ảnh hưởng của văn hoá bên ngoài, người Việt đã tiếp thu hệ thống lịch pháp cũng như một số ngày Tết quan trọng, trong đó có Tết Nguyên Đán của người Trung Quốc. Thế nhưng, cái Tết của người Trung Quốc đã hoà nhập vào cả một chuỗi những hội hè vào các tháng nghỉ khi thời tiết chuyển mùa đầu năm truyền thống của những người nông dân Việt Nam. Và rồi, cái Tết Nguyên Đán kia dần dần đã từ một lễ hội chuyển mùa đầu năm trở thành Tết Cả khởi đầu cho hàng loạt những lễ hội mùa xuân truyền thống với nhiều lễ thức và trò chơi dân gian mang đậm tính chất phồn thực âm dương, sinh trưởng và phát triển, như: tục làm bánh trưng, bánh dày, đánh đu, kéo co, chọi gà, thả chim, múa rồng, trồng cây nêu, chơi cờ người... của người Việt.

Không chỉ Tết của người Việt, mà Tết năm mới của nhiều dân tộc miền núi phía Bắc Việt Nam cũng đều bắt đầu sớm hơn chừng một hoặc hai tháng so với Tết năm mới của các dân tộc khác ở Đông Nam Á. Và, cũng như người Việt, nhiều dân tộc miền núi phía Bắc Việt Nam nói riêng và Bắc Đông Dương nói chung đã tiếp nhận và đón cái Tết của người Trung Quốc. Thế nhưng, do chịu ảnh hưởng còn chưa thật mạnh, cho nên, nhiều dân tộc miền Bắc Việt Nam vẫn coi trọng những ngày hội xuân xuống đồng truyền thống của mình hơn. Có thể thấy rõ điều này qua lễ hội Lồng Tông (xuống đồng) của người Tày và một loạt những lễ hội mùa xuân truyền thống của các dân tộc miền núi phía Bắc Việt Nam.

Sau khi đón Tết Nguyên Đán cho có lệ, từ mồng Hai Tết trở ra đến hết tháng Giêng, người Tày mới thực sự bước vào những ngày lễ hội đầu năm lớn nhất tưng bừng nhất của mình - 1ễ hội Lồng tông. Mục đích của lễ hội Lồng tông là tổ chức những ngày vui họp mặt sau một mùa làm ăn của cộng đồng để cầu mùa. Vì diễn ra theo khu vực dân cư, nên lễ hội diễn ra không trùng vào một ngày ở khắp nơi mà vào những ngày khác nhau trong tháng Giêng do từng địa phương chọn. Lễ hội thường chỉ gói trọn trong một ngày, thế nhưng, cũng có nơi kéo dài tới ba, thậm chí bốn ngày. Ngoài những lễ thức dâng cúng thần linh, trời đất, là những trò chơi dân gian cổ truyền mang đầy tính chất phồn thực âm dương như tức còn (ném còn), xẻ thỏi (kéo co), ván fằn fè (gieo giống má), tức xáng (đánh quay), tức yến (đánh một loại cầu lông), kỳ lằn (múa sư tử), 
phát tàng (mở đường)... Không còn nghi ngờ gì,như các nhà nghiên cứu đã nhận thấy, hội Lồng tông là lễ hội đầu năm của người Tày mở đầu cho một chu kỳ sản xuất, cho nên mọi nghi thức, nghi lễ, thậm chí cả các trò chơi của người lớn và trẻ nhỏ đều nhằm vào mục đích cầu mong sinh sôi, phát triển ${ }^{8}$. Như người Tày, sau khi gặt hái xong, người Giáy cũng có lễ hội xuống đồng Roóng poọc (nghĩa là: xuống hội). Tại lễ hội này, ngoài các lễ cúng, cũng diễn ra những trò chơi mang tính phồn thực nhằm cầu mong sinh sôi, phát triển như ném còn qua những chiếc vòng mặt trời, mặt trăng; trai gái kéo co... Thế nhưng, đối với người Giáy, Roóng poọc là Tết cả và được tổ chức vào tháng Giêng hàng năm. Tính chất của lễ hội đầu năm chuyển mùa còn được thể hiện rõ qua bài cúng của ông thầy mo: "Ngày này tốt, Năm này lành, Hết năm cũ, Vào năm mới, Cả bản, cả muoòng, Xuống đồng, ra bãi, Để vui choi, Mời thần bản về dụ, Giữ cho bản mường yên, Giữ ao cá ruộng lúa, Đau ốm không vào, Lúa đầy ruộng, cá đầy suối."

Dù một số nhóm tộc người đã sử dụng Âm lịch của người Trung Quốc, nhưng như nhiều dân tộc ở phía Bắc Đông Dương, lễ Tết đầu năm của người Lahu vùng Tam giác vàng ${ }^{10}$ cũng được tổ chức vào những ngày khác nhau của thời gian chuyển mùa tại những làng khác nhau, tuỳ theo sự tính toán của các già làng. Nhìn chung, thời gian tổ chức Tết năm mới là phải vào lúc công việc đồng áng đã xong, không ai còn phải đi nương hay ra ruộng nữa. Dù rằng phải đợi xem khi nào thì cả làng cùng làm Tết, nhưng, các công việc chuẩn bị cho Tết đã được bắt đầu từ trước đó cả tháng: phụ nữ phải làm quần áo mới cho các thành viên gia đình, vì, những ngày Tết là dịp mọi người, đặc biệt là trai, gái đến tuổi thành niên, xuất hiện đẹp nhất và đầy đủ mọi trang sức lễ phục trên người. Và, những ngày hội Tết năm mới bắt đầu bằng việc ông thầy lễ của làng thông báo cho mọi người biết là phải làm bánh $p a p a$ (các loại bánh được làm bằng gạo) vào ngày hôm sau. Gia đình nhà ông thấy lễ là gia đình đầu tiên của làng làm bánh $p a p a$. Làm xong, ông thầy lễ bắn súng làm hiệu để mọi nhà bắt tay vào làm bánh tết $p a p a$. Thế là, trong mỗi nhà, mọi người ngồi quây xung quanh cái cối giã để cùng làm nào là bánh để cúng, nào là bánh để ăn. Suốt ngày hôm đó, những người trẻ tuổi thì ra đồng hái cho thật nhiều rau tươi ngon, còn những người đàn ông thì vào rừng chặt cây năm mới (leh $d z u h)$ đem về cho nhà mình. Khi mặt trời đã lặn, từ trong ngôi miếu thờ thần bảo hộ của làng, ông thầy lễ của làng thông báo là, sau khi mặt trời lặn, các gia đình phải dựng cây năm mới lên ở trước nhà. Sau đấy là lễ tiễn năm cũ. Để làm lễ này, các gia đình phải "tẩy uế" nhà cửa bằng quyết bỏ đi hết mọi thứ rác bẩn và cả những đồ ăn cũ. Tối hôm đó, mọi người sẽ được nhận những quả trứng luộc chín và những sợ chỉ đầu năm. Thoạt đầu, những quả trứng và những sợi chỉ được dặt vào cái chậu có gạo nếp. Người cao tuồi nhất trong nhà bưng cái chậu đó ra ngoài nhà và cầu xin các linh hồn tổ tiên nhập vào những quả trứng và những sợi chỉ. Sau lễ thức linh thiêng đó, chiếc chậu được bưng vào nhà, mỗi người được ăn một quả trứng và được buộc vào cổ (đối với người lớn) vào cổ tay (đối với trẻ con và khách) một sợi chỉ. Tới khuya, ông thầy cúng cao niên của làng nhập đồng, ngậm nước phun và dùng lửa xua để đuổi mọi điều xấu xa của năm cũ ra khỏi nhà mình và ra khỏi làng và để làm cho mọi thứ của năm mới được sạch sẽ và tốt lành. Sau đấy, khi trời đã rất khuya, mọi người đến tập họp tại nhà ông thầy lễ. Trong khi những người già uống rượu và hát, thì bọn trẻ là những người đầu tiên ra nhảy múa xung quanh cây năm mới của nhà ông thầy lễ. Sau đấy, bọn trẻ kéo cả đoàn đến từng nhà nhảy múa quanh cây năm mới để tống khứ

\footnotetext{
${ }^{8}$ Xem: Viện Dân tộc học, Các dân tộc Tày Nùng ở Việt Nam, Hà Nội, 1992.

${ }^{9}$ Theo: Hoàng Lương, Lễ hội truyền thống của các dân tộc thiểu số ở miền bắc Việt Nam, Nxb. Văn hoá dân tộc, Hà Nội,2002, tr. 83 - 88 .

${ }^{10}$ Người Lahu, một trong những dân tộc Tạng - Miến, có số lượng 450 ngàn người (theo điều tra giữa năm 1983), sống ở vùng Tam giác vàng, trên lãnh thổ của bốn nước: Trung Quốc (250 ngàn người), Mianma (150 ngàn), Thái Lan (40 ngàn) và Lào (10 ngàn).
} 
mọi thứ xấu xa ra khỏi làng. Khi gà gáy sáng, những người phụ nữ, từ nhà ông thầy lễ, đi ra nguồn nước để dâng cúng hương, bánh và thịt lợn và để lấy nước năm mới về nhà. Nước năm mới này được dùng để giót vào các ly nước cúng trên bàn thờ và để làm những thức ăn dâng cúng tổ tiên. Ông thầy lễ của làng cùng vợ đến bên cây năm mới, dùng một ít nước năm mới lau mặt để rửa đi những tội lỗi của năm cũ. Sáng hôm đó, những người đàn ông của các gia đình cùng ông thầy lễ đến ngôi miếu của làng dâng lễ (gồm bánh gạo, rượu và thịt lợn) cho thần làng. Trong lúc dâng lễ, ông thầy cầu khấn: “... như dòng suối, như nước sạch, hãy ban cho chúng tôi sức khoẻ và bình an... Xin Ngài hãy đến nhận lễ của chúng tôi." Sau đấy, từng ông chủ hộ các gia đình mang những đồ lễ tương tự đến nhà ông thầy lễ. Ông thầy đặt các đồ lê̂ xuống nền chiếc bàn thờ của mình và cũng khấn những lời cầu mong mọi sự tốt lành. Những sợ chỉ được buộc lên cổ những người có mặt, và, mọi người lại nhảy múa và ca hát. Cứ thế, trong cả ngày đầu năm mới và cả ngày hôm sau, đâu đâu cũng rộn ràng trong tiếng nhạc, điệu múa. Mọi sự cáu giận, cãi cọ... đều là những điều cấm kỵ trong suốt những ngày Tết. Tảng sáng ngày cuối cùng của lễ hội năm mới, ông thầy lễ của làng thông báo là "mặt trời đã mọc" để mọi người biết rằng, lễ thức năm mới đã hết. Và, để biểu lộ cho sự kết thúc những lễ thức cũng như những ngày hội năm mới, mỗi gia đình đều lấy một miếng thịt lợn và hai cái bánh gạo buộc vào cây năm mới rồi đem cây năm mới ném vào rừng. ${ }^{11}$

Như vậy, dù có những khác biệt về thời gian diễn ra lễ hội và về hình thức tổ chức, những ngày lễ hội hay Tết năm mới của nhiều dân tộc Đông Nam Á, về thực chất là những ngày lễ hội thực sự mang ý nghĩa chuyển mùa: cả mùa thời tiết và mùa làm ăn. Tết của Đông Nam Á là mùa “ $n g h i$ ngơi" của không chỉ thiên nhiên mà còn của cả con người. Suốt mấy tháng cuối năm là cả một khoảng thời gian thiên nhiên chuyển mình để bước từ trạng thái cũ (mùa khô) sang một trạng thái mới (mùa mưa). Đây là khoảng thời gian rất đẹp cho con người nghỉ ngơi, vui chơi và làm những công việc không phải đồng áng, vì cái khô đã được làm dịu đi bằng những cơn mưa nhỏ thưa thớt, còn mùa mưa tầm tã thì còn chưa tới. Vào khoảng thời gian này, con người cũng thực sự được nhàn hạ và no đủ vì mùa màng đã thu hoạch xong, lúa đã về đầy kho, trong khi đó thì chưa thể làm đồng áng được vì trời còn lâu mới mưa. Thế là thiên, nhân tương hợp trong mấy tháng chuyển mùa này. Chính hoàn cảnh thiên nhiên đã tạo ra ở Đông Nam Á một nền văn hoá lấy gieo trồng cây lúa làm cơ bản. Và, vòng đời của cây lúa lại trải dài ra gần như hết cả một chu trình thời tiết, từ mùa mưa này đến mùa mưa sau. Rất hay là vòng đời của cây lúa ngắn hơn chu trình thời tiết vài tháng. Kết quả là, mấy tháng chuyển tiếp của khí hậu trở thành quãng thời gian hay những tháng nhàn rỗi nhất trong năm để mọi người tổ chức mọi cuộc vui, mọi lễ thức hội hè. Chính vì thế, Tết năm mới ở Đông Nam Á thường là cả một khoảng thời gian lễ thức, hội hè dài cả một mùa chứ không chỉ diễn ra một vài ngày. Không phải ngẫu nhiên mà người Tây Nguyên gọi các tháng lễ hội chuyển mùa là những tháng "quên" hay những tháng "nghi".

Thế rồi, trên cái nền của những lễ hội chuyển mùa chung đó, do những hoàn cảnh lịch sử khác nhau tác động, một số dân tộc ở Đông Nam Á đã khoác lên phức thể lễ hội chuyển mùa truyền thống của mình cái áo choàng của những nền văn hoá hay tôn giáo khác nhau từ bên ngoài du nhập vào. Chính vì thế mới có Tết của Việt Nam, Tết của Lào, Tết của Cămpuchia, Tết của Thái Lan, Tết của Mianma... Dù có khoác thêm tấm áo nào đi nữa, những cái Tết năm mới của Đông Nam Á vẫn toát lên một đặc trưng chung thống nhất: đặc trưng chuyển mùa từ mùa khô sang mùa mưa và từ mùa cấy trồng này sang mùa cấy trồng sau.

\footnotetext{
${ }^{11}$ Về người Lahu, có thể tham khảo: Paul and Elaine Lewis, Peoples of the Golden Triangle, Thames and Hudson, Chiang Rai, Thailand, 1984.
} 